\section{Warming up the Cold War}

Daniel S. Greenberg

Techno-Diplomacy: US-Soviet Confrontations in Science and Technology. By Glenn E. Schweitzer. Plenum: 1989. Pp.320. \$22.95.

EARLY in the Cold War, Glenn Schweitzer went to Moscow as the scientific officer at the US embassy. Ever since then he has been deeply involved in one of the most perplexing and disputed aspects of the rivalry between the superpowers their relations in science and technology, which have been maintained to some degree even during the most uneasy periods of the past 30 years.

To the Reagan administration, visiting Soviet scientists were spies, and research in the Soviet Union was too backward to warrant the interest of US scientists. The Reaganites also rejected as infantile the hope that contact with science in the United States would soften Soviet ideology and promote reforms in harmony with Western interests. Schweitzer, who is now staff director for Soviet and Eastern European Affairs at the National Academy of Sciences, makes the contrary case. The issue of 'warmer' or 'cooler' research relations has at present been rendered moot by the glow of glasnost but, as Schweitzer points out, the pendulum has swung many times in the post-war years, and may yet swing again. In brief, he makes three points. First, that scientific exchanges are a poor way of collecting strategically valuable research data, and therefore should not be curtailed because of fears of espionage; second, that although Soviet science and technology lag in many fields, other areas are so advanced that US self-interest dictates collaboration with Soviet researchers; and third, that Soviet scientific and technical contacts have helped "blunt the edge of the US-USSR military confrontation", to which, intriguingly, is added the remark that "in Washington, their importance as a rudder of political stability in the rough turbulence of USSoviet relations has yet to be adequately recognized".

The book contains an odd mixture of officialese and platitudes ("Capabilities in science and engineering spring from a nation's educational system") and fascinating, but often all-too-brief accounts of Schweitzer's personal experience of Soviet science, technology and higher education. For instance, referring to the academic process of thesis defence, he writes: "I have attended some of these sessions; sometimes they are filled with scientific controversy, while on other occasions they seem almost pro forma in satisfying an academic requirement". And that's it. Elsewhere, he expresses himself forcefully as when he assails one of the ideological hatchet men of the Reagan era, Richard Perle, for his opposition to Soviet-US scientific relations.

There is no indulgence in romanticism about the brotherhood of science to be found here: for example, "Tourism sometimes becomes a principal motivation for American scientists to participate in exchanges. . . . The ballet and the monastery visits can set the timetable". Likewise, a trip to the West is coveted by Soviet scientists because it gives them the opportunity for a shopping spree. Nor does Schweitzer dispute the contention that the Soviets prey upon Western science and technology to redress their own deficiencies in research. He insists, however, that although Western technology has been useful in some instances, it is not the backbone of the Soviet Union's formidable military power. Furthermore, he points out that technologies that originate in the civilian sector - semiconductors, for example - are increasingly vital to military systems, and are increasingly available on world markets.

Throughout, the weight of the argument is that the strategic risks of scientific amity have been exaggerated while the benefits, scientific and political, have been obscured by right-wing misrepresentations. Along the way, Schweitzer challenges the conventional grumping about Soviet visits to US research facilities, pointing out that exchanges are not an easy way of forging ahead in science. He was formerly director of a laboratory of the Environmental Protection Agency, and notes that he "led many attempts to transfer scientific techniques from our institution to others.... We had very advanced techniques, the other laboratories needed them to comply with environmental regulations, and we were eager to facilitate the technology transfer". Nonetheless, bureaucratic inertia and differences in equipment and training requirements meant the process was a time-consuming and difficult one.

As I have mentioned, Schweitzer credits Soviet-US scientific relations with an important role in getting the two countries safely through the Cold War. He suggests that the Soviet Union's scientific window on the West contributed to the country's astonishing ideological turnabout by vividly showing up that country's scientific and technological backwardness. And, on behalf of US interests, he pleads for even closer ties amid the turbulence and uncertainties that currently afflict the Soviet Union.

"Let us hope", he writes, "that our two countries are rapidly emerging from the adolescence of scientific nationalism Most importantly, American scientists have known and respected for many years Soviet scientific colleagues who are now members of Gorbachev's brain trust and who fully appreciate the need to redirect the Soviet scientific enterprise toward peaceful purposes. The likelihood of their doing so depends to a large extent on the US response to the new opportunities for relaxation of military tensions and for scientific cooperation".

This, he concludes, "is the challenge of techno-diplomacy".

Daniel S. Greenberg is at 3736 Kanawha Street NW, Washington, DC 20015, USA.

\section{Risky business}

\section{Lawrence Freedman}

Defending Deterrence: Managing the ABM Treaty Regime Into the 21st Century. Edited by Antonia H. Chayes and Paul Doty. Pergamon-Brassey's, McLean, Virginia: 1989. Pp.286. \$32, £20.

The 1972 Anti-Ballistic Missile (ABM) Treaty remains one of the most solid achievements of arms control. It was a product of the US-Soviet detente of the early 1970 s which came to be associated, eventually, to his embarrassment, with

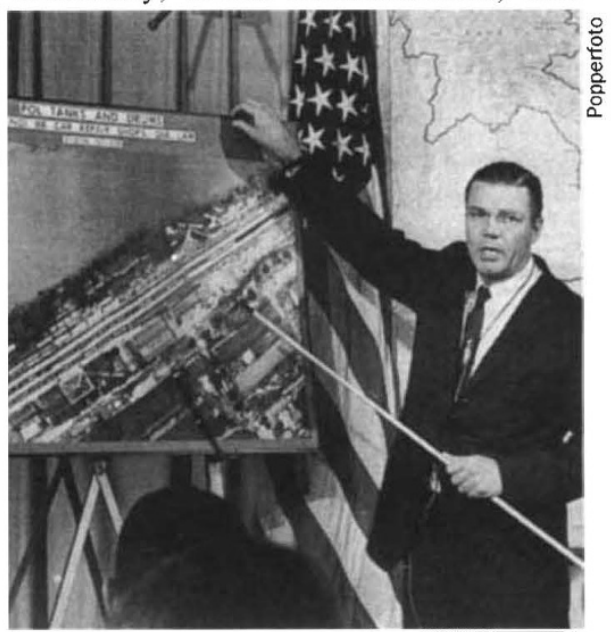

McNamara giving a Pentagon press conference during the Vietnam war, 1960.

the name of Henry Kissinger. The United States was suffering from the trauma of the Vietnam war and the Soviet Union appeared to be ascendant. Kissinger's hope was to declare a stalemate, create a Soviet stake in the status quo, and so prevent a more fundamental challenge to Western interests.

The initiative which eventually led to the treaty can be traced back to the ideas associated with Robert McNamara, US Secretary of Defense for much of the 1960s. While Kissinger understood stability largely in terms of a political arrangement with the Soviet Union, of which an arms-control treaty was an important component, McNamara saw it more as a 